\title{
RISK FACTORS FOR THE OCCURRENCE OF POTENTIAL DRUG-DRUG INTERACTIONS IN SURGICAL PATIENTS
}

Milos N. Milosavljevic ${ }^{1}$, Aleksandar G. Kocovic ${ }^{1}$, Slobodan M. Jankovic ${ }^{2}$, Dragce M. Radovanovic ${ }^{3}$, Slobodan S. Milisavljevic ${ }^{3}$ and Srdjan M. Stefanovic ${ }^{1}$ ${ }^{1}$ University of Kragujevac, Serbia, Faculty of Medical Sciences, Department of Pharmacy

${ }^{2}$ University of Kragujevac, Serbia, Faculty of Medical Sciences, Department of Pharmacology and Toxicology

${ }^{3}$ University of Kragujevac, Serbia, Faculty of Medical Sciences, Department of Surgery

\section{FAKTORI RIZIKA ZA POJAVU POTENCIJALNIH INTERAKCIJA LEKOVA KOD HIRURŠKIH PACIJENATA}

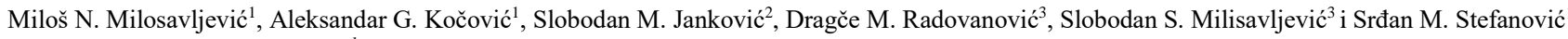
${ }^{1}$ Univerzitet u Kragujevcu, Srbija, Fakultet medicinskih nauka, Katedra za farmaciju

${ }^{2}$ Univerzitet u Kragujevcu, Srbija, Fakultet medicinskih nauka, Katedra za farmakologiju i toksikologiju

${ }^{3}$ Univerzitet u Kragujevcu, Srbija, Fakultet medicinskih nauka, Katedra za hirurgiju

\section{ABSTRACT}

Background: Drug-drug interactions are defined as modifications of the drug action that result from the simultaneous administration of another individual drug or several drugs. Nowadays, potential drug-drug interactions (DDIs) are most frequently detected and analyzed using personal digital assistant software programs (online interaction checker tools).

Objective: To determine the risk factors for the emergence of all drug-drug interactions in surgical patients with particular emphasis on clinically significant interactions.

Patients and methods: This was a retrospective cohort analysis of patients treated at the Surgical Clinic of the Clinical Center Kragujevac. Three interaction checkers were used to reveal drugdrug interactions: Medscape, Epocrates and Micromedex.

Results: The study included total of 200 patients, aged $58.54 \pm 17.08$ years. Average number of drug-drug interactions

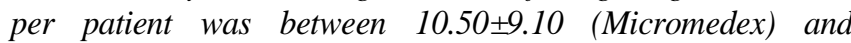
18.75 \pm 17.14 (Epocrates). Number of prescribed drugs, antidepressive therapy, antiarrhythmic therapy, number of pharmacological/therapeutic subgroups (2nd level of ATC classification) prescribed, delirium or dementia, diabetes, heart failure, and number of physicians who prescribed drugs to single patient were identified as risk factors for drug-drug interactions while length of hospitalization in days and age of patient in years emerged as protective factors.

Conclusion: Drug-drug interactions are relatively common in surgical patients and predisposed by factors such as number of prescribed drugs or drug group per patient, number of physicians who prescribed drugs, antidepressive therapy, antiarrhythmic therapy, presence of delirium or dementia, diabetes and heart failure. On the other hand, prolonged hospitalization and higher age are factors that reduce the risk of interactions in surgical patients.

Keywords: Drug-drug interactions, Risk factors, Surgery patients, Micromedex, Epocrates, Medscape.

\section{sciendo}

UDK: 615.015.2:617-089-052

Ser J Exp Clin Res 2021; 22 (3): 213-223

DOI: $10.2478 /$ sjecr-2019-0032

\section{SAŽETAK}

Uvod: Interakcije lekova se mogu definisati kao promene u delovanju leka koje nastaju kao posledica istovremene primene dva ili više leka. U današnje vreme, potencijalne interakcije lekova se najčešće identifikuju i analiziraju primenom odgovarajućih softverskih programa (online Internet čekera).

Cilj: Cilj rada bio je da se odrede faktori rizika za nastanak interakcija između lekova kod hirurških pacijenata sa posebnim osvrtom na klinički značajne interakcije.

Pacijenti i metode: Studija je dizajnirana kao retrospektivna kohortna studija kojom su analizirani pacijenti lečeni na hirurškoj klinici Kliničkog centra Kragujevac. Za otkrivanje interakcija korišćena su tri različita čekera: Medscape, Epocrates i Micromedex.

Rezultati: Studija je uključila ukupno 200 pacijenata prosečne starosti $58.54 \pm 17.08$ godina. Prosečan broj potencijalnih interakcija lekova bio je između $10.50 \pm 9.10$ (Micromedex) $18.75 \pm 17.14$ (Epocrates). Broj propisanih lekova, primena antidepresiva, primena antiaritmika, broj propisanih farmakoloških/terapeutskih podgrupa (drugi nivo ATC klasifikacije lekova), prisustvo delirijuma ili demencije, dijabetes, srčana insuficijencija i broj lekara koji su propisali lekove su se izdvojili kao faktori rizika za nastanak interakcija između lekova, dok su se dužina hospitalizacije u danima i starost pacijenata izdvojili kao protektivni faktori.

Zaključak: Interakcije lekova su relativno česte kod hirurških pacijenata i predisponirane su faktorima kao što su broj propisanih lekova ili grupa lekova, broj lekara koji su propisali lekove, antidepresivna terapija, antiaritmijska terapija, prisustvo delirijuma ili demencije, dijabetes melitusa i srčane insuficijencije. $S$ druge strane, produžena hospitalizacije i starija životna dob su faktori koji smanjuju rizik od pojave interakcija kod hirurških pacijenata.

Ključne reči: interakcije lekova, faktori rizika, hirurški pacijenti, Micormedex, Epocrates, Medscapeinterakcije lekova, faktori rizika, hirurški pacijenti, Micormedex, Epocrates, Medscape.

Corresponding author: Aleksandar G. Kocovic Faculty of Medical Sciences University of Kragujevac Svetozara Markovica 69 34000 Kragujevac, Serbia +381646603606
salekkg91@gmail.com 


\section{INTRODUCTION}

Drug-drug interactions (DDIs) are defined as modifications in the drug action resulting from the simultaneous administration of another individual drug or several drugs (12). DDIs could be of pharmacokinetic or pharmacodynamics nature, when absorption, distribution, metabolism or elimination of the drug are being altered as a consequence of the concurrent use of another drug or drugs, when interacting drugs have an additive, synergistic or antagonistic effect, respectively (1). A particular attention should be paid to classification of DDIs according to severity. The highest clinical importance have contraindicated and major (avoid to use) DDIs, although moderate and minor interactions could also suggest necessary changes in patient's pharmacotherapy (23). Nowadays, potential DDIs (pDDIs) are most frequently detected and classified using personal digital assistant software programs, which function as applications that are regularly updated (4). There are several online available tolls for such purpose and among them, the most important and the most commonly used are Micromedex Drug Interactions (5), Pharmavista (6), Epocrates (7) Lexi-Interact (8) and Medscape (9).

Epidemiological data on the incidence of pDDIs in hospitalized patients are inconsistent, with quite variable detection of interactions in previous studies ranging from 5 to 80 percent (10). However, it seems that clinically significant interactions are not so common (11-12) given their incidence of up to $4 \%$ (10). Clinically significant interactions are the reason for hospitalization in 3\% of patients (13), and when occur during hospitalization they could be associated with the prolonged stay in hospital, increased morbidity (14) and mortality (15), and the significant higher cost of treatment (16).

Previous studies have pointed several risk factors that are associated with a higher incidence of interactions in hospitalized patients, such as patients older age, prolonged hospital treatment (17), presence of comorbidities (18), polypharmacotherapy and greater number of physicians prescribing drugs to patients (3). Available data on pDDIs in surgical patients indicate that interactions often include drugs such as H2 receptor blockers, warfarin, digoxin and anesthetics (1920). These data are available from the studies that were carried out before the onset of the Interaction checkers and before the implementation of many novel drugs in clinical practice, so it could be said that the predisposing factors and the clinical significance of pDDIs in surgical patients are quite unknown. Therefore, the aim of this study was to determine the risk factors for the emergence of all pDDIs in surgical patients with particular emphasis on clinically significant interactions.

\section{PATIENTS AND METHOD}

\section{Study design}

We conducted a retrospective cohort study on patients who were treated at the Surgical Clinic of the Clinical Center Kragujevac (CCK), during the period from March $1^{\text {st }}$ to August $31^{\text {st }}$ 2018. According to structural organization of a Surgery clinic of CCK the patients that have been hospitalized at following departments were observed: Department of chest surgery, Department of general and endocrine surgery, Department of biliopancreatic surgery, Department of gastrointestinal surgery and Department of colorectal surgery. The study was approved by the Ethics Committee of CCK. The main outcome was number of pDDIs by each interaction checker tool.

\section{Data collection}

Data were collected by reviewing the medical files of patients. The complete medical documentation of the patients during their hospitalization i.e.: discharge papers, temperature-therapeutic lists, the laboratory analysis of blood and urine, data from all consultative examinations and other useful documentation, were available to research investigators. Within our study we have analyzed a large number of variables: basic socio-demographic data of the patients (age, gender, data on the consumption of alcohol and cigarettes), clinical history data (main diagnosis, length of hospitalization in days, transfer from other departments to the Surgical Clinic, presence of mechanical ventilation, conducted operations, state of consciousness), qualitative presentation of comorbidities (presence of dementia or delirium, renal failure, liver cirrhosis, diabetes mellitus, chronic obstructive pulmonary disease, bronchial asthma, hypertension, heart failure), Charlson Comorbidity Index to quantify the effect of comorbidities, number of physicians who prescribed therapy to a particular patient, data on prescribed medication during hospitalization of a particular patient (total number of prescribed drugs, number of different pharmacological/therapeutic subgroups prescribed according to Anatomical Therapeutic Chemical Classification codes, prescribing certain groups of drugs such as antidepressants, anticonvulsants, anticoagulants, antiarrhythmic and antiaggregation drugs) and interaction checker data (number and description of the DDI).

\section{Checking of DDI}

The presence of potential interactions and their classification was determined for each hospital day for each patient using three relevant interaction checker databases which operate on the principle of Internet applications: Medscape (9), Epocrates (7) and Micromedex (5). Given that these checkers have their own systems of classification of interactions based on severity, according to Medscape, DDI could be categorized as Contraindicated, Serious- Use alternative, Monitor closely and Minor, while Epocrates classifies them as Contraindicated, Avoid/use alternative, Monitor/modify therapy and Caution advised, and Micromedex separates them into 
Contraindicated, Major, Moderate and Minor drug-drug interactions.

\section{Data analysis}

The study data were analyzed by descriptive statistics and presented in tables. Mean and standard deviation was used as a measure of central tendency and dispersion for continuous variables. Values of categorical variables were presented as rates or percentages. Influence of potential risk factors on number of drug-drug interactions per patient was evaluated by multiple linear regression analysis. Statistical validity of the regression was checked by analysis of variance ( $F$ value) and percentage of outcome (number of DDIs per patient) variability explained $\left(\mathrm{R}^{2}\right)$. Influence of potential risk factors on number of DDIs per patient was assessed by their B coefficients within the regression equation, including confidence intervals (CIs). All calculations were performed by the Statistical Program for Social Sciences (SPSS version 20).

\section{RESULTS}

The study included 200 patients who were hospitalized in five surgery departments. Characteristics of the patients are shown in the Table 1 . Twenty two patients (11\%) didn't have a single drug-drug interaction detected by any of the used interaction checkers. Average number of potential drug-drug interactions detected by each of the interaction checkers is shown in the Table 2.

The largest number of potential drug-drug interactions was detected by Epocrates (3749), followed by Medscape (3466) and Micromedex (2100). Number of Contraindicated and Avoid/use alternative interactions detected by Epocrates was 681 (18.1\% of pDDIs), Contraindicated and Serious-Use alternative interactions detected by Medscape was 553 (16.0\% of pDDIs) and Contraindicated and Major interactions detected by Micromedex was 1492 (71.0\% of pDDIs).

Table 1. Characteristics of the study sample

\begin{tabular}{|c|c|}
\hline Variable & Mean \pm standard deviation (range) or number (\%) \\
\hline Age (years) & $58.54 \pm 17.08\left(\begin{array}{ll}18 & 92\end{array}\right)$ \\
\hline \multirow[t]{2}{*}{ Gender } & Male: 97 (48.5\%) \\
\hline & Female: 103 (51.5\%) \\
\hline Length of hospitalization (days) & $6.63 \pm 4.14\left(\begin{array}{ll}1 & 29\end{array}\right)$ \\
\hline Transfer from another ward & $2(1.0 \%)$ \\
\hline Transfer from emergency department & $130(65.0 \%)$ \\
\hline Transfer from intensive care unit & $2(1.0 \%)$ \\
\hline $\begin{array}{l}\text { At least one day of immobilization because of ag- } \\
\text { itation }\end{array}$ & $7(3.5 \%)$ \\
\hline Inability to stand up from the bed & $10(5.0 \%)$ \\
\hline Number of prescribed drugs & $15.36 \pm 7.16(3-38)$ \\
\hline $\begin{array}{l}\text { Number of pharmacological/therapeutic sub- } \\
\text { groups (2nd level of ATC classification) pre- } \\
\text { scribed }\end{array}$ & $11.17 \pm 5.03(224)$ \\
\hline $\begin{array}{l}\text { Number of physicians who prescribed drugs to } \\
\text { single patient }\end{array}$ & $2.05 \pm 0.996(17)$ \\
\hline Surgery & $112(56.0 \%)$ \\
\hline Charlson Comorbidity Index & $1.58 \pm 2.37(0-10)$ \\
\hline Delirium or dementia & $5(2.5 \%)$ \\
\hline Renal failure & $3(1.5 \%)$ \\
\hline Liver cirrhosis & $1(0.5 \%)$ \\
\hline Diabetes & $29(14.5 \%)$ \\
\hline Chronic obstructive pulmonary disease & $12(6.0 \%)$ \\
\hline Asthma & $3(1.5 \%)$ \\
\hline Hypertension & $101(50.5 \%)$ \\
\hline Heart failure & $30(15.0 \%)$ \\
\hline Anticoagulant therapy & $100(50.0 \%)$ \\
\hline Drug allergy & $13(6.5 \%)$ \\
\hline Antidepressants & $5(2.5 \%)$ \\
\hline Antiarrhythmic drugs & $9(4.5 \%)$ \\
\hline Mechanical ventilation & $3(1.5 \%)$ \\
\hline Coma & $1(0.5 \%)$ \\
\hline
\end{tabular}


Table 2. Average number of potential drug-drug interactions per patient by checker

\begin{tabular}{|l|l|}
\hline \multicolumn{1}{|c|}{ Type of interaction } & \multicolumn{1}{c|}{ Mean \pm standard deviation (range) } \\
\hline Medscape & \\
\hline Contraindicated & $0.00 \pm 0.00(0-0)$ \\
\hline Serious - Use alternative & $2.81 \pm 2.66(0-10)$ \\
\hline Monitor closely & $11.76 \pm 10.66(0-49)$ \\
\hline Minor & $2.75 \pm 3.12(0-17)$ \\
\hline Total & $17.33 \pm 15.34(0-67)$ \\
\hline & \\
\hline Epocrates & \\
\hline Contraindicated & $0.29 \pm 0.47(0-2)$ \\
\hline Avoid/use alternative & $3.13 \pm 3.09(0-12)$ \\
\hline Monitor/modify therapy & $10.41 \pm 10.02(0-41)$ \\
\hline Caution advised & $4.92 \pm 5.15(0-17)$ \\
\hline Total & $18.75 \pm 17.14(0-67)$ \\
\hline & \\
\hline Micromedex & \\
\hline Contraindicated & $0.60 \pm 0.63(0-2)$ \\
\hline Major & $6.92 \pm 6.46(0-27)$ \\
\hline Moderate & $2.75 \pm 3.03(0-15)$ \\
\hline Minor & $0.22 \pm 0,50(0-2)$ \\
\hline Total & $10.50 \pm 9.10(0-38)$ \\
\hline
\end{tabular}

Results of the last step of the backward multiple linear regression analysis are presented in the Tables 3-5. Comparing all significant independent factors that entered the final regression model 18 different factors were identified from a total of 21. These factors in descending order and the number of times when factor entered the final model are: number of prescribed drugs (7), surgery (6), number of pharmacologi$\mathrm{cal} /$ therapeutic subgroups (2nd level of ATC classification) prescribed (5), length of hospitalization (days) (5), hypertension (5), antiarrhythmic therapy (4), chronic obstructive pulmonary disease (4), Charlson comorbidity index (3), transfer from emergency department (3), delirium or dementia (3), diabetes (3), antidepressive therapy (2), heart failure (2), anticoagulant therapy (2), number of physicians who prescribed drugs to single patient (2), inability to stand up from the bed (1), age (years) (1) and drug allergy (1).

Eight factors were positively correlated with number of DDIs, i.e. in other words, we can say that they contribute to the occurrence of DDIs: number of prescribed drugs, antidepressive therapy, antiarrhythmic therapy, number of pharmacological/therapeutic subgroups (2nd level of ATC classification) prescribed, delirium or dementia, diabetes, heart failure, and number of physicians who prescribed drugs to single patient. Two factors were negatively correlated with number of DDIs (protective factors): length of hospitalization in days and age of patient in years.

Surgery was positively correlated with number of Serious - Use alternative interactions by Medscape (Table 3), number of Avoid/use alternative, Monitor/modify therapy and Caution advised interactions by Epocrates (Table 4) and number of Major interactions by Micromedex (Table 5) but was found to be negatively correlated with the number of Minor interactions by Micromedex (Table 5). It was shown that hypertension was a risk factor for higher number of Monitor closely and Minor interactions by Medscape (Table 3), higher number of Monitor/modify therapy interactions by Epocrates (Table 4) and higher number of Moderate interactions by Micromedex (Table 5) but in same time was protective factor for the occurrence of Caution advised interactions by Epocrates (Table 4). Patients with chronic obstructive pulmonary disease had lower number of Avoid/use alternative and Monitor/modify therapy interactions by Epocrates (Table 4) and number of Major interactions by Micromedex (Table 5) but also had a higher number of Minor interactions by Micromedex (Table 5). Charlson Comorbidity Index was associated with less Minor interactions by Medscape (Table 3) and Minor interactions by Micromedex (Table 5) and with more Monitor/modify therapy interactions by Epocrates (Table 4). Transfer from emergency department was positively correlated with number of Serious - Use alternative interactions by Medscape (Table 3), but was negatively correlated with the number of Monitor closely interactions by Medscape (Table 3) and number of Moderate interactions by Micromedex (Table 5). Positive association was shown between anticoagulant therapy and number of Major interactions by Micromedex (Table 5), and negative association between anticoagulant therapy and number of Caution advised interactions by Epocrates (Table 4). 
Table 3. Variables included in the last step of the model for potential drug-drug interactions detected by Medscape

\begin{tabular}{|c|c|c|c|}
\hline Variables & $\mathbf{B}$ & $\mathbf{P}$ & $95 \%$ CI \\
\hline \multicolumn{4}{|c|}{ Serious - Use alternative interaction } \\
\hline Constant & -1.852 & $<0.001^{*}$ & -2.435 to -1.269 \\
\hline Number of prescribed drugs & 0.206 & $<0.001^{*}$ & 0.165 to 0.248 \\
\hline $\begin{array}{l}\text { Transfer from emergency de- } \\
\text { partment }\end{array}$ & 0.461 & $0.037^{*}$ & 0.029 to 0.893 \\
\hline Surgery & 1.932 & $<0.001^{*}$ & 1.308 to 2.557 \\
\hline Antidepressive therapy & 1.315 & $0.037^{*}$ & 0.078 to 2.552 \\
\hline Antiarrhythmic therapy & 1.697 & $<0.001^{*}$ & 0.756 to 2.638 \\
\hline $\mathrm{R}^{2} ; \mathrm{F}(\mathrm{p})$ & \multicolumn{3}{|c|}{$0.750 ; 116.144\left(<0.001^{*}\right)$} \\
\hline \multicolumn{4}{|l|}{ Monitor closely interaction } \\
\hline Constant & -4.520 & $<0.001^{*}$ & -6.840 to -2.201 \\
\hline Number of prescribed drugs & 0.565 & $<0.001^{*}$ & 0.269 to 0.860 \\
\hline $\begin{array}{l}\text { Number of pharmacologi- } \\
\text { cal/therapeutic subgroups (2nd } \\
\text { level of ATC classification) } \\
\text { prescribed }\end{array}$ & 0.835 & $<0.001^{*}$ & 0.408 to 1.263 \\
\hline Delirium or dementia & 5.208 & $0.029^{*}$ & 0.548 to 9.869 \\
\hline $\begin{array}{l}\text { Length of hospitalization } \\
\text { (days) }\end{array}$ & -0.351 & $<0.001^{*}$ & -0.547 to -0.156 \\
\hline $\begin{array}{l}\text { Transfer from emergency de- } \\
\text { partment }\end{array}$ & -2.206 & $0.010^{*}$, & -3.879 to -0.533 \\
\hline Diabetes & 3.878 & $0.001^{*}$ & 1.683 to 6.073 \\
\hline Hypertension & 2.079 & $0.008^{*}$ & 0.543 to 3.615 \\
\hline Antiarrhythmic therapy & 6.657 & $<0.001^{*}$ & 3.123 to 10.190 \\
\hline $\mathrm{R}^{2} ; \mathrm{F}(\mathrm{p})$ & \multicolumn{3}{|c|}{$0.783 ; 85.907\left(<0.001^{*}\right)$} \\
\hline \multicolumn{4}{|l|}{ Minor interaction } \\
\hline Constant & -1.845 & $<0.001^{*}$ & -2.535 to -1.156 \\
\hline Number of prescribed drugs & 0.257 & $<0.001^{*}$ & 0.216 to 0.298 \\
\hline Delirium or dementia & 1.898 & $0.044^{*}$ & 0.052 to 3.744 \\
\hline Charlson Comorbidity Index & -0.279 & $<0.001^{*}$ & -0.416 to -0.143 \\
\hline Diabetes & 2.601 & $<0.001^{*}$ & 1.695 to 3.507 \\
\hline Hypertension & 1.302 & $<0.001^{*}$ & 0.685 to 1.920 \\
\hline Drug allergy & -1.057 & 0.070 & -2.203 to 0.089 \\
\hline Antidepressants & 3.281 & $<0.001^{*}$ & 1.456 to 5.106 \\
\hline $\mathrm{R}^{2} ; \mathrm{F}(\mathrm{p})$ & \multicolumn{3}{|c|}{$0.606 ; 42.152\left(<0.001^{*}\right)$} \\
\hline
\end{tabular}

Table 4. Variables included in the last step of the model for potential drug-drug interactions detected by Epocrates

\begin{tabular}{|l|l|l|l|}
\hline \multicolumn{1}{|c|}{ Variables } & \multicolumn{1}{c|}{ B } & \multicolumn{1}{c|}{ 95\% CI } \\
\hline Avoid/use alternative interaction & -0.288 & 0.610 & -1.401 to 0.824 \\
\hline Constant & -0.016 & 0.067 & -0.033 to 0.001 \\
\hline Age (years) & 0.197 & $<0.001^{*}$ & 0.137 to 0.258 \\
\hline Number of prescribed drugs & 2,281 & $<0.001^{*}$ & 1.411 to 3.152 \\
\hline Surgery & $-2,189$ & $<0.001^{*}$ & -3.330 to -1.047 \\
\hline Chronic obstructive pulmonary disease & 0.833 & $0.043^{*}$ & 0.026 to 1.641 \\
\hline Heart failure & & & \\
\hline
\end{tabular}




\begin{tabular}{|c|c|c|c|}
\hline Variables & B & $\mathbf{p}$ & $95 \%$ CI \\
\hline Antiarrhythmic therapy & 1,257 & 0.056 & -0.034 to 2.547 \\
\hline $\mathrm{R}^{2} ; \mathrm{F}(\mathrm{p})$ & \multicolumn{3}{|c|}{$0.649 ; 59.465\left(<0.001^{*}\right)$} \\
\hline \multicolumn{4}{|l|}{ Monitor/modify therapy interaction } \\
\hline Constant & -6.076 & $<0.001^{*}$ & -7.954 to -4.197 \\
\hline Number of prescribed drugs & 0.617 & $<0.001^{*}$ & 0.316 to 0.918 \\
\hline $\begin{array}{l}\text { Number of pharmacological/therapeutic subgroups } \\
\text { (2nd level of ATC classification) prescribed }\end{array}$ & 0.511 & $0.023^{*}$ & 0.071 to 0.950 \\
\hline Charlson Comorbidity Index & 0.426 & $0.009^{*}$ & 0.108 to 0.744 \\
\hline Length of hospitalization (days) & -0.373 & $<0.001^{*}$ & -0.561 to -0.184 \\
\hline $\begin{array}{l}\text { At least one day of immobilization because of agi- } \\
\text { tation }\end{array}$ & 4.245 & 0.050 & 0.004 to 8.486 \\
\hline Inability to stand up from the bed & -3.129 & 0.077 & -6.605 to 0.347 \\
\hline Surgery & 3.681 & $0.004^{*}$ & 1.209 to 6.153 \\
\hline Chronic obstructive pulmonary disease & -3.458 & $0.030^{*}$ & -6.576 to -0.340 \\
\hline Hypertension & 2.474 & $0.002^{*}$ & 0.903 to 4.045 \\
\hline $\mathrm{R}^{2} ; \mathrm{F}(\mathrm{p})$ & \multicolumn{3}{|c|}{$0.784 ; 76.477\left(<0.001^{*}\right)$} \\
\hline \multicolumn{4}{|l|}{ Caution advised interaction } \\
\hline Constant & -2.930 & $<0.001^{*}$ & -4.007 to -1.852 \\
\hline Number of prescribed drugs & 0.297 & $<0.001^{*}$ & 0.133 to 0.462 \\
\hline $\begin{array}{l}\text { Number of pharmacological/therapeutic subgroups } \\
\text { (2nd level of ATC classification) prescribed }\end{array}$ & 0.391 & $0.002^{*}$ & 0.146 to 0.635 \\
\hline Length of hospitalization (days) & -0.197 & $<0.001^{*}$ & -0.304 to -0.089 \\
\hline Surgery & 1.983 & $0.007^{*}$ & 0.536 to 3.430 \\
\hline Hypertension & -0.906 & $0.041^{*}$ & -1.777 to -0.036 \\
\hline Anticoagulant therapy & -1.194 & $0.019^{*}$ & -2.192 to -0.196 \\
\hline Drug allergy & 1.662 & $0.040^{*}$ & 0.074 to 3.251 \\
\hline Antidepressants & 2.332 & 0.070 & -0.190 to 4.854 \\
\hline $\mathrm{R}^{2} ; \mathrm{F}(\mathrm{p})$ & \multicolumn{3}{|c|}{$0.726 ; 63.187\left(<0.001^{*}\right)$} \\
\hline
\end{tabular}

Table 5. Variables included in the last step of the model for potential drug-drug interactions detected by Micromedex

\begin{tabular}{|l|l|l|l|}
\hline \multicolumn{1}{|c|}{ Variables } & \multicolumn{1}{c|}{ B } & \multicolumn{1}{c|}{ 95\% CI } \\
\hline Major interaction & -0.352 & 0.723 & -2.312 to 1.608 \\
\hline Constant & -0.032 & $0.033^{*}$ & -0.060 to -0.003 \\
\hline Age (years) & 0.457 & $<0.001^{*}$ & 0.337 to 0.577 \\
\hline Number of prescribed drugs & -0.164 & $0.009^{*}$ & -0.287 to -0.042 \\
\hline Length of hospitalization (days) & 3.390 & $<0.001^{*}$ & 1.783 to 4.996 \\
\hline Surgery & -2.821 & $0.005^{*}$ & -4.801 to -0.841 \\
\hline Chronic obstructive pulmonary disease & 2.615 & $<0.001^{*}$ & 1.450 to 3.781 \\
\hline Anticoagulant therapy & 3.193 & $0.006^{*}$ & 0.928 to 5.457 \\
\hline Antiarrhythmic therapy & $0.756 ; 84.890\left(<0.001^{*}\right)$ & \\
\hline $\mathrm{R}^{2} ; \mathrm{F}$ (p) & \multicolumn{3}{|l|}{} \\
\hline \multicolumn{3}{|l|}{} \\
\hline Moderate interaction & -0.934 & -1.793 to -0.074 \\
\hline Constant & $0.033^{*}$ & 0.262 to 0.376 \\
\hline $\begin{array}{l}\text { Number of pharmacological/therapeutic subgroups } \\
\text { (2nd level of ATC classification) prescribed }\end{array}$ & 0.319 & $<0.001^{*}$ \\
\hline
\end{tabular}




\begin{tabular}{|c|c|c|c|}
\hline Variables & B & $\mathbf{p}$ & $95 \% \mathrm{CI}$ \\
\hline $\begin{array}{l}\text { Number of physicians who prescribed drugs to sin- } \\
\text { gle patient }\end{array}$ & 0.332 & $0.020^{*}$ & 0.053 to 0.611 \\
\hline Delirium or dementia & 2.198 & $0.009^{*}$ & 0.559 to 3.836 \\
\hline Charlson Comorbidity Index & -0.113 & 0.069 & -0.234 to 0.009 \\
\hline Length of hospitalization (days) & -0.132 & $<0.001^{*}$ & -0.203 to -0.061 \\
\hline Transfer from emergency department & -0.904 & $0.003^{*}$ & -1.488 to -0.321 \\
\hline Diabetes & 2.337 & $<0.001^{*}$ & 1.546 to 3.129 \\
\hline Hypertension & 1.132 & $<0.001^{*}$ & 0.575 to 1.690 \\
\hline Heart failure & 0.884 & $0.020^{*}$ & 0.138 to 1.629 \\
\hline $\mathrm{R}^{2} ; \mathrm{F}(\mathrm{p})$ & \multicolumn{3}{|c|}{$0.690 ; 47.032\left(<0.001^{*}\right)$} \\
\hline \multicolumn{4}{|l|}{ Minor interaction } \\
\hline Constant & -0.155 & 0.096 & -0.337 to 0.028 \\
\hline $\begin{array}{l}\text { Number of pharmacological/therapeutic subgroups } \\
\text { (2nd level of ATC classification) prescribed }\end{array}$ & 0.030 & $0.005^{*}$ & 0.009 to 0.050 \\
\hline $\begin{array}{l}\text { Number of physicians who prescribed drugs to sin- } \\
\text { gle patient }\end{array}$ & 0.089 & $0.016^{*}$ & 0.017 to 0.161 \\
\hline Charlson Comorbidity Index & -0.031 & $0.031^{*}$ & -0.060 to -0.003 \\
\hline Inability to stand up from the bed & 0.373 & $0.015^{*}$ & 0.072 to 0.674 \\
\hline Surgery & -0.276 & $0.006^{*}$ & -0.472 to -0.081 \\
\hline Chronic obstructive pulmonary disease & 0.503 & $<0.001^{*}$ & 0.229 to 0.776 \\
\hline Antiarrhythmic drugs & 0.409 & $0.010^{*}$ & 0.097 to 0.722 \\
\hline $\mathrm{R}^{2} ; \mathrm{F}(\mathrm{p})$ & \multicolumn{3}{|c|}{$0.242 ; 8.758\left(<0.001^{*}\right)$} \\
\hline
\end{tabular}

The Table 6 shows the most common contraindicated/serious/major interactions detected by the interaction checkers. The most frequently occurring interaction was between

fentanyl and sevoflurane which was detected by Medscape interaction checker in 98 (49.0\%) patients.

Table 6. The most frequent contraindicated/serious/major potential interactions detected by the interaction checkers

\begin{tabular}{|c|c|c|}
\hline Drug combinations & Description & $\begin{array}{c}\text { Number (\%) of } \\
\text { patients }\end{array}$ \\
\hline \multicolumn{3}{|l|}{ Medscape } \\
\hline \multicolumn{3}{|l|}{ Serious - Use alternative } \\
\hline 1. Fentanyl + sevoflurane & $\begin{array}{l}\text { Either increases effects of the other by } \\
\text { pharmacodynamic synergism }\end{array}$ & $98(49.0 \%)$ \\
\hline 2. $\quad$ Fentanyl + propofol & $\begin{array}{l}\text { Either increases effects of the other by } \\
\text { pharmacodynamic synergism }\end{array}$ & 95 (47.5\%) \\
\hline 3. $\quad$ Fentanyl + rocuronium & $\begin{array}{l}\text { Either increases effects of the other by } \\
\text { pharmacodynamic synergism }\end{array}$ & $81(40.5 \%)$ \\
\hline 4. $\quad$ Fentanyl + tramadol & $\begin{array}{l}\text { Either increases effects of the other by } \\
\text { pharmacodynamic synergism }\end{array}$ & $74(37.0 \%)$ \\
\hline 5. Diclofenac + ketorolac & $\begin{array}{l}\text { Either increases toxicity of the other by } \\
\text { pharmacodynamic synergism. }\end{array}$ & $23(11.5 \%)$ \\
\hline
\end{tabular}




\begin{tabular}{|c|c|c|}
\hline Drug combinations & Description & $\begin{array}{c}\text { Number }(\%) \text { of } \\
\text { patients }\end{array}$ \\
\hline \multicolumn{3}{|l|}{ Epocrates } \\
\hline \multicolumn{3}{|l|}{ Contraindicated } \\
\hline 1. Atropine + potassium chloride & $\begin{array}{l}\text { Combo may delay solid potassium pas- } \\
\text { sage through GI tract, increased risk of } \\
\text { ulcerative/stenotic lesions }\end{array}$ & $44(22.0 \%)$ \\
\hline 2. Potassium chloride + scopolamine & $\begin{array}{l}\text { Combo may delay solid potassium pas- } \\
\text { sage through GI tract, increased risk of } \\
\text { ulcerative/stenotic lesions }\end{array}$ & $8(4.0 \%)$ \\
\hline 3. Aspirin + ketorolac & Combo may increase risk of GI bleeding, & $6(3.0 \%)$ \\
\hline \multicolumn{3}{|l|}{ Avoid/use alternative } \\
\hline 1. Ondansetron + sevofluran & $\begin{array}{l}\text { Combo may increase risk of QT prolon- } \\
\text { gation, cardiac arrhythmias }\end{array}$ & $78(39.0 \%)$ \\
\hline 2. Fentanyl + midazolam & $\begin{array}{l}\text { Combo may increase risk of profound } \\
\text { CNS and resp. depression, psychomotor } \\
\text { impairment }\end{array}$ & $73(36.5 \%)$ \\
\hline 3. Fentanyl + tramadol & $\begin{array}{l}\text { Combo may increase risk of profound } \\
\text { CNS and resp. depression, psychomotor } \\
\text { impairment }\end{array}$ & $73(36.5 \%)$ \\
\hline 4. Ondansetron + tramadol & $\begin{array}{l}\text { Combo may increase risk of QT prolon- } \\
\text { gation, cardiac arrhythmias }\end{array}$ & $59(29.5 \%)$ \\
\hline 5. Fentanyl + potassium chloride & $\begin{array}{l}\text { Combo may delay solid potassium pas- } \\
\text { sage through GI tract, increased risk of } \\
\text { ulcerative/stenotic lesions }\end{array}$ & $53(26.5 \%)$ \\
\hline \multicolumn{3}{|l|}{ Micromedex } \\
\hline \multicolumn{3}{|l|}{ Contraindicated } \\
\hline 1. Atropine + potassium chloride & $\begin{array}{l}\text { Concurrent use may result in risk of gas- } \\
\text { trointestinal lesions. }\end{array}$ & $78(39.0 \%)$ \\
\hline 2. Diclofenac + ketorolac & Enhanced gastrointestinal adverse effects & $23(11.5 \%)$ \\
\hline 3. Aspirin + ketorolac & Gastrointestinal adverse effects & $7(3.5 \%)$ \\
\hline 4. Potassium chloride + scopolamine & $\begin{array}{l}\text { Concurrent use may result in risk of gas- } \\
\text { trointestinal lesions. }\end{array}$ & $7(3.5 \%)$ \\
\hline 5. Haloperidol + metoclopramide & $\begin{array}{l}\text { Concurrent use may result in an in- } \\
\text { creased risk of extrapyramidal reactions } \\
\text { and neuroleptic malignant syndrome. }\end{array}$ & $1(0.5 \%)$ \\
\hline \multicolumn{3}{|c|}{ 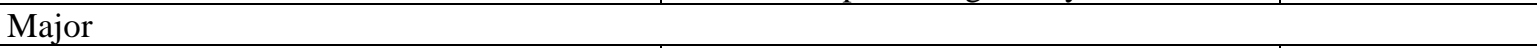 } \\
\hline 1. Fentanyl + propofol & $\begin{array}{l}\text { Concurrent use may result in increased } \\
\text { risk of CNS depression. }\end{array}$ & $91(45.5 \%)$ \\
\hline 2. Ondansetron + sevoflurane & $\begin{array}{l}\text { Concurrent use may result in increased } \\
\text { risk of QT-interval prolongation. }\end{array}$ & $76(38.0 \%)$ \\
\hline 3. Fentanyl + ranitidine & $\begin{array}{l}\text { Concurrent use may result in increased } \\
\text { risk of fentanyl toxicity. }\end{array}$ & 75 (37.5\%) \\
\hline 4. $\quad$ Ranitidine + tramadol & $\begin{array}{l}\text { Concurrent use may result in increased } \\
\text { tramadol exposure and increased risk of } \\
\text { respiratory depression. }\end{array}$ & 75 (37.5\%) \\
\hline 5. $\quad$ Fentanyl + tramadol & $\begin{array}{l}\text { Concurrent use may result in increased } \\
\text { risk of respiratory and CNS depression; } \\
\text { increased risk of serotonin syndrome. }\end{array}$ & $74(37.0 \%)$ \\
\hline
\end{tabular}

\section{DISCUSSION}

We showed that the occurrence of DDIs is predisposed by factors such as number of prescribed drugs, number of pharmacological/therapeutic subgroups, prescribed antidepressants, antiarrhythmic drugs, number of physicians who prescribed drugs to single patient, delirium or dementia, diabetes, and heart failure. On the other hand, length of hospitalization and age of patients are set as factors that reduce the risk of DDIs. There are also factors, such as surgery, hypertension, chronic obstructive pulmonary disease, Charlson Comorbidity Index, transfer from emergency department and anticoagulant therapy, whose impact is equivocal and depend 
on the incidence of DDIs depends on the checker used for detection of DDIs as well as on the type of interaction.

The increase in the number of prescribed medication carries a higher risk for the occurrence of DDIs, and we could say that the results of our study are consistent with the results of other authors $(12,21-22)$. A significant risk factor for the occurrence of DDIs in our study is related to the use of antiarrhythmic drugs, which is also demonstrated in other studies (3). Most of antiarrhythmics are metabolized via the cytochrome P450 enzyme system, so they can interact with a number of cytochrome P450 inducers / inhibitors. Because of their narrow therapeutic window, interactions of antiarrhythmics generally have a serious clinical character (23). We also found that use of antidepressants is also related with higher risk od DDIs occurrence in surgical patients, which also can be easily explained by the basic pharmacological properties of these drugs. Fluoxetine and paroxetine are potent inhibitors of CYP2D6, fluvoxamine and nefazodone inhibit CYP3A4, while tricyclic antidepressants and monoamine oxidase inhibitors beside pharmacokinetic interactions, have a significant potential for pharmacodynamic interactions (24).

Most of patients included in our study had one or more comorbidities, which were mostly treated in the same way as before hospitalization. Presence of comorbidities in patients represents a significant risk factor for the occurrence of interactions (25). In our study, we found positive correlation between number of DDIs and presence of diabetes, heart failure and dementia/delirium. Hypertension was positively correlated with clinical significant interactions and negatively correlated with DDIs of minor clinical significance, while the presence of chronic obstructive pulmonary disease (COPD) paradoxically meant a lower risk of occurrence of clinically significant interactions. The results of previous studies (2627) suggest that the presence of cardiac diseases represents a significant risk factor for the occurrence of interactions. This is due the fact that cardiovascular diseases, particularly heart failure and severe hypertension, are treated with a combination of drugs such as beta-blockers, ACE inhibitors, diuretics and digoxin, which have a notable potential to interact with other drugs (28). Additionally, anticoagulation and antiaggregation drugs are often used to prevent unwanted cardiovascular events. Among these drugs, a particularly high potential for interaction has warfarin due to it is metabolized via the cytochrome P450 enzyme system (29). We showed that use of anticoagulants increases the risk of major DDIs, and because of that, there is a necessity of special caution when prescribing these drugs. Of antidiabetic drugs, sulfonylurea derivatives have a serious potential for interactions with other drugs at the cytochrome P450 level in liver, whereas metformin should be used with caution in patients receiving nephrotoxic drugs, primarily NSAIDs (30). In this possible lies the explanation of the result of our study in which the presence of diabetes mellitus in surgical patients significantly increased the risk of DDIs. Patients with delirium in our study were treated with haloperidol, a typical antipsychotic that interacts with other CNS depressants (31), but also with metoclopramide (32), which was also commonly used antiemetic in patients enrolled in this study. This is in line with the finding we of our study, in which the presence of delirium was identified as a significant risk factor for the occurrence of interactions. When we talk about chronic obstructive pulmonary disease, we found that presence of COPD was protective factor for the occurrence of significant DDIs, but also factor which predispose the occurrence of minor DDIs. Similar results were reported by a group of authors from Slovenia (3334), who showed that the interactions in patients with COPD are frequent, but that they were of minor clinical relevance.

Surgical intervention during hospitalization in our study was related to increased number of clinical significance DDIs. It is known that in surgical patients interactions typically occur during the use of warfarin, digoxin and drugs used for anesthesia of patients (19-20). In our study the most commonly clinical significant DDIs by all of three used checkers were interactions that involved drugs used for general anesthesia of patients. In addition to general anesthetics, opiod analgesics fentanyl and tramadol, antiemetic ondansetron and ranitidine were included within these interactions. Interactions between general anesthetics and clinical analgesics have been predicted and found to be useful in clinical practice due to the synergistic hypnotic and analgesic effect (35), but a great caution is needed when combining these drugs in order to avoid over-hypnosis of patients and the occurrence of a coma. The number of DDIs in patients who undergo surgical interventions is also increased due to the introduction of antibiotic prophylaxis as well as the treatment of postoperative pain (36). It has also been shown in our study, given that among the most common clinically significant DDIs were interactions involving NSAIDs, such as diclofenac and ketorolac. This combination of drugs can be considered as contraindicated due to the fact that such practice does not increase the effectiveness of analgesic therapy, while the toxic effects of NSAIDs on the kidneys and stomach become more pronounced.

The elderly takes a greater number of drugs in general, with consequently increased risk of DDIs (37). The results of our study, on the other hand, show that the risk of interaction is reduced with increasing age of patients. This phenomenon can be explained in several ways. Firstly, as we have previously stated, in the most commonly detected DDIs in our patients participated the drugs used for the preoperative anesthesia of patients. Despite significant progress in the field of anesthesiology and postoperative care of patients, it could be said that operations that are not essential to a patient's life are not routinely performed in elderly patients due to the more common occurrence of postoperative complications and a higher rate of morbidity and mortality (38). Also, in our study, we examined the risk factors for the emergence of interactions in surgical patients, while studies that showed an opposite effect of age on the incidence of DDIs $(11,37)$ were conducted on patients hospitalized in several different wards. Therefore, there is a necessity for conducting new studies on a larger sample of surgical patients in order to examine this phenomenon. 
Increased duration of stay in the hospital is associated with a higher risk of DDIs $(3,15)$. However, in our study, we found that length of hospitalization could be a protective factor for the occurrence of DDIs in surgical patients. We could say that the length of hospitalization has an indirect impact on the incidence of DDIs, since the extension of the hospitalization increases the number of drugs that are prescribed to patients. Since the study by Jankovic et al (3) was also conducted on patients who were hospitalized at the Clinical Center Kragujevac but in the intensive care unit, the explanation of this phenomenon should be sought in the differences in the functioning of these departments. In the intensive care unit of the Clinical Center in Kragujevac are treated life-threatening condition in patients with indications that require the use of a large number of drugs and prolonged treatment. On the other hand, patients in the surgical department generally have better conditions and their extended stay is usually the consequence of a postoperative infection of the wound, which requires the introduction of antibiotic therapy. Antibiotics do not have such a great potential for interactions with other drugs, as shown in our research, since the interactions of antibiotics with other drugs were not so frequent.

Finally, it is important to emphasize that our study has significant limitations. The first limitation relates to a relatively modest sample size of patients who were surgically treated in a single center; therefore, there is a possibility that it did not reveal all factors which might be associated with the occurrence of DDIs in surgical patients. Second important shortcoming of our study relates to the disadvantages of the applications (online checkers) used for detection of DDIs. This applies in particular to Medscape and Epocrates, because these checkers do not offer the possibility of checking potential DDIs for drugs such as nadroparin and bromazepam, that were relatively frequently administered in our patients. Also, this study was related to the theoretical presentation of potential DDIs in surgical patients, while the practical significance of most of these interactions was not the subject of this study.

In conclusion, we could say that DDIs in surgical patients are relatively common and that their occurrence is predisposed by factors such as number of prescribed drugs or drug group per patient, number of physicians who prescribed drugs, antidepressive therapy, antiarrhythmic therapy, delirium or dementia, diabetes and heart failure. On the other hand, length of hospitalization and age are factors that reduce the risk of interactions in surgical patients. The most common interactions in surgical patients are those which include the drugs used for the preoperative anesthesia of patients, whose synergistic effect is mostly predictable and desirable. However, the combination of these drugs requires great caution because in case of overdose there is a risk of respiratory depression, coma and even death of the patient. The online applications widely used nowadays for detection potential DDIs are quite effective, but they have some disadvantages that need to be corrected.

\section{ACKNOWLEDGEMENTS}

This study was partially supported by bilateral scientific project between Serbia and Montenegro entitled "Risk factors for DDIs in tertiary care hospitals”.

\section{REFERENCES}

1. May JR, DiPiro JT, Sisley JF. (1987). Drug interactions in surgical patients. Am J Surg, 153(3):327-35.

2. Hasan SS, Lim KN, Anwar M, et al. (2012). Impact of pharmacists' intervention on identification and management of drug-drug interactions in an intensive care setting. Singapore Med J, 53(8):526-31.

3. Janković SM, Pejčić AV, Milosavljević MN, et al. (2018). Risk factors for potential drug-drug interactions in intensive care unit patients. J Crit Care, 43:1-6.

4. Kheshti R, Aalipour M, Namazi S. (2016). A comparison of five common drug-drug interaction software programs regarding accuracy and comprehensiveness. J Res Pharm Pract, 5(4):257-263.

5. Truven Health Analtytics LLC, Micromedex ${ }^{\circledR}$ Solutions,https://www.micromedexsolutions.com/ home/dispatch/PFDefaultActionId/pf.LoginAction/ssl/ true?redirected=true; 2019 [accessed 20.03.2019].
6. Pharmavista-information for healthcare proffesionals, http://www.pharmavista.ch/content/default.aspx?http:// www.pharmavista.ch/content/NewsMaker.aspx?ID=44 39\&NMID=4421\&LANGID=3; 2019 [accessed 20.02. 2019].

7. Epocrates, Inc. Interaction Checker. https://online.epocrates.com/interaction-check; 2019 [accessed 20.02.2019].

8. Lexi-Comp OnlineTM, Pediatric Lexi-Drugs OnlineTM, Hudson, Ohio: Lexi-Comp, Inc.; 2019, www.lexi.com/institutions/products/online/;2019 [accessed 20.02.2019].

9. Medscape. Multi-Drug Interaction checker. http:// reference.medscape.com/druginteractionchecker; 2019 [accessed 20.02.2019].

10. Lubinga SJ, Uwiduhaye E. (2011). Potential drug-drug interactions on in-patient medication prescriptions at Mbarara Regional Referral Hospital (MRRH) in western Uganda: prevalence, clinical importance and associated factors. Afr Health Sci, 11(3):499-507. 
11. Bjerrum L, Gonzalez Lopez-Valcarcel B, Petersen G. (2008). Risk factors for potential drug interactions in general practice. Eur J Gen Pract, 14(1):23-9.

12. Gagne JJ, Maio V, Rabinowitz C. (2008). Prevalence and predictors of potential drug-drug interactions in Regione Emilia-Romagna, Italy. J Clin Pharm Ther, 33(2):141-51.

13. Lazarou J, Pomeranz BH, Corey PN. (1998). Incidence of adverse drug reactions in hospitalized patients: a meta-analysis of prospective studies. JAMA, 279(15):1200-5.

14. Vonbach P, Dubied A, Krähenbühl S, Beer JH. (2008). Prevalence of drug-drug interactions at hospital entry and during hospital stay of patients in internal medicine. Eur J Intern Med, 19(6):413-20.

15. Moura CS, Acurcio FA, Belo NO. (2009). Drug-drug interactions associated with length of stay and cost of hospitalization. J Pharm Pharm Sci, 12(3):266-72.

16. Becker ML, Kallewaard M, Caspers PW, Visser LE, Leufkens HG, Stricker BH. (2007). Hospitalisations and emergency department visits due to drug-drug interactions: a literature review. Pharmacoepidemiol Drug Saf, 16(6):641-51.

17. Murtaza G, Khan MY, Azhar S, Khan SA, Khan TM. (2016). Assessment of potential drug-drug interactions and its associated factors in the hospitalized cardiac patients. Saudi Pharm J, 24(2):220-5.

18. Ahmad A, Khan MU, Haque I, et al. (2015). Evaluation of potential drug - drug interactions in general medicine ward of teaching hospital in southern India. J Clin Diagn Res, 9(2):FC10-3.

19. Durrence CW 3rd, DiPiro JT, May JR, Nesbit RR Jr, Sisley JF, Cooper JW. (1985). Potential drug interactions in surgical patients. Am J Hosp Pharm, 42(7):1553-6.

20. May JR, DiPiro JT, Sisley JF. (1987). Drug interactions in surgical patients. Am J Surg, 153(3):327-35.

21. Chatsisvili A, Sapounidis I, Pavlidou G, et al. (2010). Potential drug-drug interactions in prescriptions dispensed in community pharmacies in Greece. Pharm. World Sci, 32(2):187-193.

22. Janchawee B, Wongpoowarak W, Owatranporn T, Chongsuvivatwong V. (2005). Pharmacoepidemiologic study of potential drug interactions in outpatients of a university hospital in Thailand. J. Clin. Pharm. Ther, 30(1):13-20.

23. Trujillo TC, Nolan PE. (2000). Antiarrhythmic agents: drug interactions of clinical significance. Drug Saf, 23(6):509-32.

24. Spina E, Scordo MG. (2002). Clinically significant drug interactions with antidepressants in the elderly. Drugs Aging, 19(4):299-320.

25. Ko Y, Malone DC, D'Agostino JV, et al. (2008). Potential determinants of prescribers' drug-drug interaction knowledge. Research in Social and Administrative Pharmacy, 4(4):355-66.
26. Doubova Dubova SV, Reyes-Morales H, TorresArreola Ldel P, Suarez-Ortega M. (2007). Potential drug-drug and drug-disease interactions in prescriptions for ambulatory patients over 50 years of age in family medicine clinics in Mexico City. BMC Health Serv Res, 7:147.

27. Cruciol-Souza JM, Thomson JC. (2006). Prevalence of potential drug-drug interactions and its associated factors in a Brazilian teaching hospital. J Pharm Pharm Sci, 9(3):427-433.

28. Straubhaar B, Krähenbühl S, Schlienger RG. (2006). The prevalence of potential drug-drug interactions in patients with heart failure at hospital discharge. Drug Saf, 29(1):79-90.

29. Mateti U, Rajakannan T, Nekkanti H, Rajesh V, Mallaysamy S, Ramachandran P. (2011). Drug-drug interactions in hospitalized cardiac patients. J Young Pharm, 3(4):329-333.

30. May M, Schindler C. (2016). Clinically and pharmacologically relevant interactions of antidiabetic drugs. Ther Adv Endocrinol Metab, 7(2):69-83.

31. Ocaña-Zurita MC, Juárez-Rojop IE, Genis A, et al. (2016). Potential drug-drug interaction in Mexican patients with schizophrenia. Int J Psychiatry Clin Pract, 20(4):249-53.

32. Okuno MF, Cintra RS, Vancini-Campanharo CR, Batista RE. (2013). Drug interaction in the emergency service. Einstein (Sao Paulo), 11(4):462-466.

33. Roblek T, Trobec K, Mrhar A, Lainscak M. (2014). Potential drug-drug interactions in hospitalized patients with chronic heart failure and chronic obstructive pulmonary disease. Arch Med Sci, 10(5):920-32.

34. Roblek T, Trobec K, Mrhar A, Lainscak M. (2012). Drug-drug interactions in hospitalized patients with chronic obstructive pulmonary disease. European Respiratory Journal, 40(56):P2159.

35. Rosow CE. (1997). Anesthetic drug interaction: an overview. J Clin Anesth, 9(6 Suppl):27S-32S.

36. Zhou L, Ma J, Gao J, Chen S, Bao J. (2016). Optimizing Prophylactic Antibiotic Practice for Cardiothoracic Surgery by Pharmacists' Effects. Medicine (Baltimore), 95(9):e2753.

37. Cruciol-Souza JM, Thomson JC. (2006). Prevalence of potential drug-drug interactions and its associated factors in a Brazilian teaching hospital. J Pharm Pharm Sci, 9(3):427-433.

38. Desserud KF, Veen T, Søreide K. (2016). Emergency general surgery in the geriatric patient. $\mathrm{Br} \mathrm{J}$ Surg, 103(2):e52-61. 